\title{
Assessments of Natural Radioactivity and Heavy Metals in Commonly Consumed Milk in Oke-Ogun Area, Nigeria and Estimation of Health Risk Hazard to the Population
}

\section{Ademola Augustine Kolapo*}

Bells University of Technology, Physics, Benja Drive, Ota, Ogun 234, Nigeria

\begin{abstract}
Eight samples of commonly consumed powdered milk by adults were collected from local markets in Oke-Ogun area, Nigeria and analyzed using gamma ray spectrometer with $\mathrm{Nal}(\mathrm{TI})$ detector for radioactive analysis and Atomic Absorption Spectrophotometer for heavy metal analysis $(\mathrm{Pb}, \mathrm{Fe}, \mathrm{Cd}$ and $\mathrm{Cu})$. The main activity concentration detected is that of $40 \mathrm{~K}$ with average of $39.6 \mathrm{~Bq} . \mathrm{kg}-1$ while the activities of $226 \mathrm{Ra}$ and $232 \mathrm{Th}$ were below detection limit (BDL). The total annual effective dose due to the ingestion of radionuclide in the milk sample was estimated to be $<33.7 \mu \mathrm{Sv}$. $y-1$ which is lower than the ICRP recommended limit of $1 \mathrm{mSv} . \mathrm{y}-1$ for all ages. The geometric means of $\mathrm{Pb}, \mathrm{Cd}, \mathrm{Fe}$ and $\mathrm{Cu}$ in the samples were found to be $0.024,0.328,2.168$ and $0.242 \mathrm{mg} . \mathrm{kg}-1$, respectively and the annual daily dose estimated were $0.1490,0.010,0.0002$ and $0.0003 \mathrm{mg}$.day- 1 , respectively. The results of the hazard index revealed that the intake of heavy metal through ingestion of the milk samples did not exceeds the recommended limit of unity. Therefore, the consumption of these milk samples is safe.
\end{abstract}

Keywords: Radionuclide; Heavy metal; Powdered milk; Oke-ogun; Ingestion

\section{Introduction}

Many dangerous radionuclides, elements or compounds such as metals and metalloids, accumulate along the food chain. Their concentrations in the environment grow with the increase of urban, agricultural, and industrial emissions. The presence of metal pollutants, like $\mathrm{Cd}$ and $\mathrm{Pb}$, aids their entry into the food chain and thereby increases the toxicity effects of the food in humans and animals diet. Milk is one of the most important foods for human nutrition; it is beneficial in human diet and mostly needed by infant and children during their growing age. Milk contains all the macronutrients namely protein, carbohydrates, fat, vitamins (A, D and B groups) and trace elements particularly calcium, phosphate, magnesium, zinc and selenium $[1,2]$. Milk is known as an excellent source of $\mathrm{Ca}$, and it can supply moderate amounts of $\mathrm{Mg}$, smaller amounts of $\mathrm{Zn}$ and very small amounts of $\mathrm{Fe}$ and $\mathrm{Cu}[3]$.

Heavy metals in human diets come mainly from milk, meat and other products frequently consumed. Investigation of heavy metals level in food products have been monitored in numerous regions of the world and there has been an increasing world-wide concern about quality of powdered milk, studies in recent years have investigated the quality of powdered milk in different parts of the world [4-11].

In Nigeria no record of radioactive contamination of the environment has been reported [12]. Some research works in radioactivity measurements of food samples in Nigeria, have been reported [11,13-15]. Among different kinds of foodstuffs, milk is a reliable indicator of the general population intake of certain radionuclides, metals and metalloids, since it is consumed by a large segment of the population. So, the determination heavy metals and natural radionuclides levels in milk and milk products is important for controlling the toxicity levels of our diets and necessary in establishing rules and regulations relating to processing and manufacturing of products. Milk is an important vector of radionuclides and heavy metals to man and they may get into the environment from the mining activities, several nuclear weapon tests and numerous nuclear reactor accidents. Contamination of the food chain may occur as a result of direct deposition of radionuclides and heavy metals on plants leave and fruits tubers, root uptake from contaminated soil or water, and animals ingesting contaminated plants, soil or water. Another important factor of contamination is the importation of contaminated food from foreign countries where nuclear accident or fall-out had occurred which can indirectly affect people health around the world. Therefore, determination of radionuclides and heavy metals in milk is of interest to know the adequate daily intake of these metals and also to determine and monitor the levels of toxicity in our diets because they can significantly influence human and animal health [16].

The aims of this study therefore are: to determine the concentration of natural radionuclides and heavy metals in 8 different brands of milk products consumed in Oke-Ogun area of Oyo State; the border between Nigeria and Benin Republic where different kinds of milk products were illegally imported into the country and to estimate the annual internal dose from the intake of the heavy metals in the milk products.

\section{Materials and Methods}

\section{Samples collection and preparations}

Eight different samples of powdered milk that were frequently consumed were collected from the local markets in Oke-Ogun. This was obtained using questionnaire where inhabitants were asked for the types of powdered milk they frequently buy and consumed.

*Corresponding author: Ademola Augustine Kolapo, Bells University of Technology, Physics, Benja Drive, Ota, Ogun 234, Nigeria, Tel: +2348059732443; E-mail: sirkay006@yahoo.com

Received November 10, 2014; Accepted November 25, 2014; Published December 06, 2014

Citation: Kolapo AA (2014) Assessments of Natural Radioactivity and Heavy Metals in Commonly Consumed Milk in Oke-Ogun Area, Nigeria and Estimation of Health Risk Hazard to the Population. J Environ Anal Toxicol 4: 253. doi: 10.4172/2161-0525.1000253

Copyright: (c) 2014 Kolapo AA, et al. This is an open-access article distributed under the terms of the Creative Commons Attribution License, which permits unrestricted use, distribution, and reproduction in any medium, provided the original author and source are credited. 
Citation: Kolapo AA (2014) Assessments of Natural Radioactivity and Heavy Metals in Commonly Consumed Milk in Oke-Ogun Area, Nigeria and Estimation of Health Risk Hazard to the Population. J Environ Anal Toxicol 4: 253. doi: 10.4172/2161-0525.1000253

Powdered milk products were sampled because it is an important ingredient used in the making of cookies, ice cream, yogurt, chocolate, powdered chocolate, candy and many others, it is a cheap and easy to store milk product which inhabitants can afford. These samples were analysed using Flame Atomic Absorption Spectrophotometer model S4 series, Model (GBC 906) (USA) for the heavy metals and gamma ray spectrometer with $\mathrm{NaI}(\mathrm{Tl})$ detector for natural radionuclides.

\section{Radionuclide analysis of samples}

One hundred gram of each sample was weighed and parked in a plastic container. The plastic containers were hermetically sealed for 30 days for secular equilibrium to be reached between parents and their daughter radionuclides [17]. Detection and measurements of the radionuclides in the powdered milk samples were carried out by gamma ray spectrometer with a $\mathrm{NaI}(\mathrm{TI})$ detector. The counting assembly was a scintillation detector and a Canberra multichannel analyzer. The detector was a $7.6 \times 7.6 \mathrm{~cm}^{2} \mathrm{NaI}(\mathrm{Tl})$ manufactured by Bicron. A cylindrical lead shield of approximately $5 \mathrm{~cm}$ thickness with a fixed bottom and a movable cover shielded the detector from background radiation. The detector assembly has a resolution of $\sim 8 \%$ at $662 \mathrm{KeV}$ of ${ }^{137} \mathrm{Cs}$.

Samples were counted for 10 hours. The activity concentration of ${ }^{214} \mathrm{~Pb}(352 \mathrm{KeV})$ and ${ }^{214} \mathrm{Bi}(609 \mathrm{KeV}, 1120 \mathrm{KeV})$ were chosen to provide an estimate of ${ }^{226} \mathrm{Ra}$, while that of the daughter radionuclides ${ }^{208} \mathrm{Ti}$ $(2651 \mathrm{KeV}),{ }^{212} \mathrm{~Pb}(239 \mathrm{KeV}),{ }^{228} \mathrm{Ac}(911 \mathrm{KeV})$ were chosen as indicator of ${ }^{232} \mathrm{Th},{ }^{40} \mathrm{~K}$ was directly measured using its single photo peak at $1460 \mathrm{KeV}$ emitter. The background count was determined by counting an empty container of the same dimensions as the one containing the samples and subtracting from the gross count. The counting time was set at $36000 \mathrm{~s}(10 \mathrm{~h})$ to obtain the gamma spectrum with good statistics. The activity concentrations in the samples were obtained using equation given elsewhere [18]. The detection limit (DL) given in $\mathrm{Bq} \mathrm{kg}^{-1}$, which is required to estimate the minimum detectable activity in a sample, was obtained using equation given in [18]. The detection limits obtained were $17.3 \mathrm{~Bq} \mathrm{~kg}^{-1}$, $4.2 \mathrm{~Bq} \mathrm{~kg}{ }^{-1}$ and $5.1 \mathrm{~Bq} \mathrm{~kg}^{-1}$ for ${ }^{40} \mathrm{~K},{ }^{226} \mathrm{Ra}^{2}$ and ${ }^{232} \mathrm{Th}$ respectively.

\section{Digestion of milk samples and elemental analysis}

One gram each of the powdered milk samples was weighed into a $100 \mathrm{~mL}$ digestion tube. Each of the tubes was labelled to avoid mix-up. A total of $5 \mathrm{~mL}$ each of nitric acid and hydrogen peroxide were added, while $\mathrm{SO}_{4}$ was added in small amount and the mixture was thoroughly stirred until white fumes evolved. The process continued until the solution is clear. The solution was decanted and diluted with deionized water up to $100 \mathrm{~mL}$ before being filtered. The procedure was repeated for all the samples. For each sample three determinations were performed and average results were reported. Before metal concentrations were determined, standard solutions were prepared in each case and were used to eliminate sample standard matrix indifferences.

The concentration of the metals in the samples were obtained from the readings of Atomic Absorption Spectrophotometer (AAS) S4 Model (GBC 906) as shown in equation (1)

Concentration of sample $=\underline{\text { AAS reading } \times 100}[1]$

Weight of samples.

\section{Average Daily dose and Health risk index (HRI)}

The health risk from heavy metal intake through ingestion may be characterized using hazard index, which is the ratio of the Average
Daily Dose (ADD in mg per kilogram of the body weight per day) of a chemical to an oral reference dose (Rf Do; in mg per kg per day) [19]. Oral reference dose is defined as the maximum tolerable daily intake of specific metal that does not result in any deleterious health effects. According to USEPA 2002 [20], oral reference doses are $0.4 \times 10^{-3}, 0.7$ and $1 \times 10^{-3} \mathrm{mg} \mathrm{kg}^{-1} \mathrm{day}^{-1}$ for $\mathrm{Cu}, \mathrm{Fe}$ and $\mathrm{Cd}$ respectively and $3.5 \times 10^{-3}$ $\mathrm{mg} \mathrm{kg}^{-1}$ day $^{-1}$ for $\mathrm{Pb}[21]$.

\section{$\mathrm{ADD}$ is expressed as:}

$$
A D D=\frac{C_{\text {metal }} \times D_{\text {ntake }}}{B_{\text {average }}}
$$

where $\mathrm{C}_{\text {metal }}$ is the geometric mean concentration of metal in the sample; $\mathrm{D}_{\text {intake }}$ is the average daily intake of the radionuclides from the consumption of the milk sample and $\mathrm{B}_{\text {average }}$ is the is the average weight of the adults taken as $70 \mathrm{~kg}$.

Exposure to heavy metal is therefore estimated as:

Hazard Index $=\frac{A D D}{R f D o}$

An index more than 1 implies that the ADD of a particular metal exceeds the RfDo which mean that there is a potential risk associated with that metal and is considered as not safe for human health [20].

\section{Results and Discussion}

\section{Radioactivity analysis of milk samples}

Table 1 show the results of the gamma-ray analysis of the eight powdered milk samples analyzed. The radionuclides observed with reliable regularity in the samples belonged to the decay series chain of ${ }^{226} \mathrm{Ra},{ }^{232} \mathrm{Th}$ and the non-series ${ }^{40} \mathrm{~K}$. The activity concentrations of ${ }^{226} \mathrm{Ra}$ and ${ }^{232} \mathrm{Th}$ in all the samples have value below detection limit (BDL). The activity concentration of ${ }^{40} \mathrm{~K}$ in the samples ranged from BDL to 195.0 $\pm 9.5 \mathrm{Bqkg}^{-1}$ with means as shown in column 3 in Table 1 . The highest activity concentration of ${ }^{40} \mathrm{~K}$ was detected in sample M5 (195.0 \pm 9.5 $\mathrm{Bqkg}^{-1}$ ) and the lowest activity concentration was obtained to be BDL in sample M8. The overall mean of ${ }^{40} \mathrm{~K}$ is $39.6 \pm 12.6 \mathrm{Bqkg}^{-1}$.

\section{Internal dose of the radionuclide from the ingestion of the} milk

The radiation dose to the population from the intake of radionuclide in foods was calculated from the equation reported in [22] as:

$$
E=A C I
$$

where $\mathrm{E}$ is the annual effective dose by ingestion of the radionuclide $\left(S v y^{-1}\right), A$ is the activity concentration of the radionuclides in the sample $\left(\mathrm{Bqkg}^{-1}\right), \mathrm{C}$ is the internal conversion factor by ingestion of the radionuclide $\left(\mathrm{Sv} \mathrm{Bq}^{-1}\right)$ [23] and $\mathrm{I}$ is the annual intake of milk $\left(\mathrm{Kgy}^{-1}\right)$ which depends on a given age $[23,24]$.

\begin{tabular}{|c|c|c|c|}
\hline Samples & ${ }^{226} \mathrm{Ra}\left(\mathrm{Bqkg}^{-1}\right)$ & ${ }^{232} \mathrm{Th}^{\left(\mathrm{Bqkg}^{-1}\right)}$ & ${ }^{40} \mathrm{~K}\left(\mathrm{Bqkg}^{-1}\right)$ \\
\hline M1 & $\mathrm{BDL}$ & $\mathrm{BDL}$ & $47.2 \pm 5.2$ \\
\hline M2 & $\mathrm{BDL}$ & $\mathrm{BDL}$ & $38.6 \pm 6.1$ \\
\hline M3 & $\mathrm{BDL}$ & $\mathrm{BDL}$ & $52.0 \pm 12.1$ \\
\hline M4 & $\mathrm{BDL}$ & $\mathrm{BDL}$ & $43.6 \pm 4.3$ \\
\hline M5 & $\mathrm{BDL}$ & $\mathrm{BDL}$ & $55.1 \pm 3.5$ \\
\hline M6 & $\mathrm{BDL}$ & $\mathrm{BDL}$ & $34.2 \pm 6.0$ \\
\hline M7 & $\mathrm{BDL}$ & $\mathrm{BDL}$ & $28.0 \pm 8.6$ \\
\hline M8 & $\mathrm{BDL}$ & $\mathrm{BDL}$ & $17.8 \pm 3.2$ \\
\hline Mean & $\mathrm{BDL}$ & $\mathrm{BDL}$ & $39.6 \pm 12.6$ \\
\hline
\end{tabular}

Table 1: Natural Radionuclide level in the powdered milk samples. 
Citation: Kolapo AA (2014) Assessments of Natural Radioactivity and Heavy Metals in Commonly Consumed Milk in Oke-Ogun Area, Nigeria and Estimation of Health Risk Hazard to the Population. J Environ Anal Toxicol 4: 253. doi: 10.4172/2161-0525.1000253

Page 3 of 5

Annual effective ingestion dose due to milk consumption is strongly dependent of the milk consumption [25]. In this study, the average mass of the milk consumed by the adults is taken as $13 \mathrm{Kg} \mathrm{y}^{-1}$ according to [26,27]. In the calculation of the total dose, the sum of the contributions from each radioisotope in the samples Table 1 with the recommended conversion factors for adults given as $6.2 \times 10^{-9}, 2.3 \times 10^{-7}$ and $2.8 \times 10^{-7}$ for ${ }^{40} \mathrm{~K},{ }^{232} \mathrm{Th}$ and ${ }^{226} \mathrm{Ra}$, respectively [23] was used.

The contributions of each radionuclide in the estimated annual effective ingestion dose are presented in Table 2. The contributions of ${ }^{226} \mathrm{Ra}$ and ${ }^{232} \mathrm{Th}$ were calculated using the value of LLD (4.2 and 5.1 $\mathrm{Bqkg}^{-1}$, respecively) since all the values obtained for ${ }^{226} \mathrm{Ra}$ and ${ }^{232} \mathrm{Th}$ in the samples were below the DL. The mean contributions of ${ }^{226} \mathrm{Ra}$ and ${ }^{232} \mathrm{Th}$ are presented as $<15.3$ and $<15.2 \mu \mathrm{Svy}^{-1}$ in column 2 and 3 in Table 2 while the mean contribution of ${ }^{40} \mathrm{~K}$ is $3.2 \mu \mathrm{Svy}^{-1}$ in column 3 , Table 2. The total average ingestion dose due to all the radionuclide in the powdered milk sample is $<33.7 \mu S v y^{-1}$. These results are within the typical worldwide range of annual dose (200- $800 \mathrm{mSv})$ due to the ingestion of all natural radiation sources reported by UNSCEAR 2000 [22].

The comparison of the results of the average activity concentrations of ${ }^{226} \mathrm{Ra},{ }^{232} \mathrm{Th}$ and ${ }^{40} \mathrm{~K}$ obtained in this work with similar published data in literature are presented in Table 3 . The results obtained for the activity concentration of ${ }^{226} \mathrm{Ra}$ and ${ }^{232} \mathrm{Th}$ in all the samples are below detection limit (BDL) and so their values are taken as BDL. The average

\begin{tabular}{|c|c|c|c|}
\hline Samples & ${ }^{226} \mathrm{Ra}\left(\mu \mathrm{Svy}^{-1}\right)$ & ${ }^{232} \mathrm{Th}\left(\mu \mathrm{Svy}^{-1}\right)$ & ${ }^{40} \mathrm{~K}\left(\mu \mathrm{Svy}^{-1}\right)$ \\
\hline M1 & 15.3 & 15.2 & 3.8 \\
\hline M2 & 15.3 & 15.2 & 3.1 \\
\hline M3 & 15.3 & 15.2 & 4.2 \\
\hline M4 & 15.3 & 15.2 & 3.5 \\
\hline M5 & 15.3 & 15.2 & 4.4 \\
\hline M6 & 15.3 & 15.2 & 2.8 \\
\hline M7 & 15.3 & 15.2 & 2.3 \\
\hline M8 & 15.3 & 15.2 & 1.4 \\
\hline Mean & 15.3 & 15.2 & 3.2 \\
\hline
\end{tabular}

Table 2: Annual effective ingestion dose due to the intake of ${ }^{226} \mathrm{Ra},{ }^{232} \mathrm{Th}$ and ${ }^{40} \mathrm{~K}$ in the powered milk samples.

\begin{tabular}{|l|l|l|l|l|}
\hline Country & 226Ra $\left(\mathrm{Bqkg}^{-1}\right)$ & 232Th $\left(\mathrm{Bqkg}^{-1}\right)$ & $40 \mathrm{~K}\left(\mathrm{Bqkg}^{-1}\right)$ & Reference \\
\hline $\begin{array}{l}\text { Nigeria (Oke- } \\
\text { Ogun) }\end{array}$ & - & - & 39.6 & Present Study \\
\hline Saudi Arabia & 9.64 & 6.77 & 74.51 & Zain, 2013 \\
\hline India & 2.50 & 1.02 & 34.35 & Shanthi et al., 2010 \\
\hline $\begin{array}{l}\text { Egypt (Alex- } \\
\text { andra) }\end{array}$ & 0.44 & - & 47.25 & Ibrahim et al., 2007 \\
\hline Iran/France & 0.05 & 0.14 & 434 & Hossein et al., 2006 \\
\hline
\end{tabular}

Table 3: Comparison of the average concentrations of ${ }^{226} \mathrm{Ra},{ }^{232} \mathrm{Th}$ and ${ }^{40} \mathrm{~K}$ with those published data in powdered milk $\left(\mathrm{Bqkg}^{-1}\right)$.

\begin{tabular}{|c|c|c|c|c|}
\hline Samples & $\mathrm{Pb}(\mathrm{mg} / \mathrm{kg})$ & $\mathrm{Cd}(\mathrm{mg} / \mathrm{kg})$ & $\mathrm{Fe}(\mathrm{mg} / \mathrm{kg})$ & $\mathrm{Cu}(\mathrm{mg} / \mathrm{kg})$ \\
\hline $\mathrm{M} 1$ & 0.034 & 0.046 & 2.705 & 0.241 \\
\hline $\mathrm{M} 2$ & 0.042 & 0.027 & 2.212 & 0.202 \\
\hline $\mathrm{M} 3$ & 0.032 & 0.043 & 1.500 & 0.171 \\
\hline $\mathrm{M} 4$ & 0.023 & 0.034 & 1.332 & 0.142 \\
\hline M5 & 0.032 & 0.041 & 1.412 & 0.350 \\
\hline M6 & 0.029 & 0.029 & 2.801 & 0.251 \\
\hline M7 & 0.026 & 0.024 & 3.111 & 0.382 \\
\hline M8 & 0.004 & 0.025 & 3.312 & 0.300 \\
\hline Mean & 0.029 & 0.034 & 2.298 & 0.255 \\
\hline Goemean & 0.024 & 0.033 & 2.168 & 0.242 \\
\hline
\end{tabular}

Table 4: Concentrations of heavy metals in the milk samples. activity concentrations for ${ }^{40} \mathrm{~K}$ in the milk samples are found to be lower than the values published in Indian [28], Egypt [29], Saudi Arabia [23] and in Iran [30] as shown in Table 3.

\section{Heavy metal composition and health risk index of the milk samples}

The heavy metal contents vary widely due to many factors such as differences between species, characteristics of the manufacturing practises and possible contamination coming from the equipments during the process [31]. The concentrations of heavy metals $(\mathrm{Pb}, \mathrm{Cd}$, $\mathrm{Fe}$ and $\mathrm{Cu}$ ) analysed in the samples are presented in Table 4 . The concentration of $\mathrm{Pb}$ ranged between $0.004 \mathrm{mgkg}^{-1}$ in sample M8 and $0.042 \mathrm{mgkg}^{-1}$ in sample M2. while that of Cd ranged between $0.024 \mathrm{mgkg}$ ${ }^{1}$ in sample M7 and $0.046 \mathrm{mgkg}^{-1}$ in sample M1. The concentrations of Fe ranged from $1.332 \mathrm{mgkg}^{-1}$ in sample M4 to $3.312 \mathrm{mgkg}^{-1}$ in sample M8 while the concentration of $\mathrm{Cu}$ ranged from $0.142 \mathrm{mgkg}^{-1}$ in sample M4 to $0.382 \mathrm{mgkg}^{-1}$ in sample M7. The geometric mean and the mean of the concentration of heavy metal in the samples were found to be $(0.029,0.024) ;(0.037,0.033) ;(2.298,2.168)$ and $(0.255,0.242) \mathrm{mgkg}$ ${ }^{1}$, respectively for $\mathrm{Pb}, \mathrm{Cd}, \mathrm{Fe}$ and $\mathrm{Cu}$. The mean concentrations of each heavy metal were compared with the permissible limit recorded in literature [32] and were found to be within the safe limit. Figure 1 compared the mean concentrations of the heavy metal in the samples. It was found that $\mathrm{Fe}$ was highest in all the samples but still within the permissible limit. Iron is an essential element that contributes to many important physiologic functions in the body and in addition $4.8 \mathrm{mg}$ has been recommended as the acceptable daily intake of Fe [33]. Traces of $\mathrm{Pb}$ found in the samples may be due to contamination of original cow's milk used in the manufacture of these products.

The ADDs and hazard indices in the milk samples were calculated using equation and 4 respectively and are presented in Table 5 . The intake (mg/day) was taken from the acceptable daily intake per 70 $\mathrm{kg}$ person (FAO/WHO, 1989 and 1999) [33,34] and is presented in column 3 in Table 5. The mean ADD calculated for the four heavy metals analyzed are $0.1490,0.0010,0.0002$ and $0.0003 \mathrm{mgkg}^{-1}$ for Fe, $\mathrm{Cu}, \mathrm{Pb}$ and $\mathrm{Cd}$, respectively and are presented in column 4 of Table 5 . The hazard index of the heavy metals in sampled powdered milk are $0.212,0.025,0.005$ and 0.300 , respectively, for $\mathrm{Fe}, \mathrm{Cu}, \mathrm{Pb}$ and $\mathrm{Cd}$, and are lower than unity as can be seen in column 5 in Table 5 . The hazard less than 1 implies that they do not pose any significant threat.

\section{Conclusion}

In this study, the radionuclide contents present in eight powdered milk commonly consumed by adults in Oke-Ogun region, Nigeria were determined using gamma ray spectroscopy. Mainly, the activity concentration of ${ }^{40} \mathrm{~K}$ was detected and the mean values $(47.2,38.6$, $52.0,43.6,55.1,34.2,28.0$ and $\left.17.8 \mathrm{Bqkg}^{-1}\right)$ lie within the recommended limit. The activity concentration of ${ }^{226} \mathrm{Ra}$ and ${ }^{232} \mathrm{Th}$ are below the

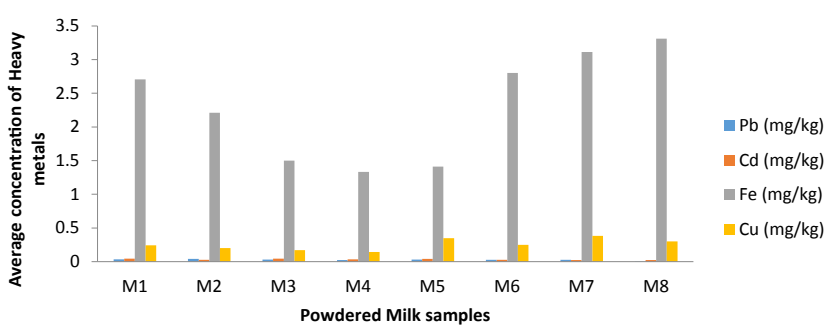

Figure 1: Comparison of heavy metals in powdered milk samples 
Citation: Kolapo AA (2014) Assessments of Natural Radioactivity and Heavy Metals in Commonly Consumed Milk in Oke-Ogun Area, Nigeria and Estimation of Health Risk Hazard to the Population. J Environ Anal Toxicol 4: 253. doi: 10.4172/2161-0525.1000253

Page 4 of 5

\begin{tabular}{|l|l|l|l|l|}
\hline Heavy metals & $\begin{array}{l}\text { RfD0 } \\
(\mathrm{mg} / \mathrm{kg} \text { body weight/day }\end{array}$ & $\begin{array}{l}\text { Geomean } \\
(\mathrm{mg} / \mathrm{kg})\end{array}$ & $\begin{array}{l}\text { Intake } \\
(\mathrm{mg} / \mathrm{day})\end{array}$ & $\begin{array}{l}\text { ADD } \\
\text { (mg/kg body weight/day) }\end{array}$ \\
\hline $\mathrm{Fe}$ & $7.000 \times 10^{-1}$ & 2.168 & 4.800 & 0.1490 \\
\hline $\mathrm{Cu}$ & $4.000 \times 10^{-2}$ & 0.242 & 0.400 & 0.212 \\
\hline $\mathrm{Pb}$ & $4.000 \times 10^{-2}$ & 0.024 & 0.500 & 0.0010 \\
\hline $\mathrm{Cd}$ & $1.000 \times 10^{-3}$ & 0.328 & 0.070 & 0.0002 \\
\hline
\end{tabular}

Table 5: Average Daily Dose (ADD) and hazard index of heavy metals due to ingestion of the milk samples.

detection limit (BDL). Therefore, the radionuclides level in the studied powdered milk samples for adults is obviously below the maximum level permitted by International Atomic Energy Agency (1989) [32]; so these kinds of milk can therefore be normally consumed. The total average annual effective dose due to the ingestion of all three natural radionuclides are found to be $<33.7 \mu S v y^{-1}$ which is far below the $1 \mathrm{mSvy}^{-1}$ recommended limit by WHO and ICRP for radiological safety. Comparison of the results obtained with those reported in literature revealed that natural radionuclides in the samples are well within the worldwide ranges.

The heavy metal analysis revealed that there were traces of heavy metal in the samples although their mean concentrations were lower than the permissible limit. Fe has the highest concentration in all the samples because it is an essential element that contributes to many important physiologic functions in the body. Average Daily Dose (ADD) was estimated taking into account the geometric mean concentration of the heavy metal. The mean ADDs in the milk samples were $0.1490,0.0010,0.0002$ and 0.0003 for $\mathrm{Fe}, \mathrm{Cu}, \mathrm{Pb}$, and $\mathrm{Cd}$, respectively which are lower than the safe limit. The hazard index which is the exposure due to the heavy metals in sampled powdered milk is $0.212,0.025,0.005$ and 0.300 , respectively, for $\mathrm{Fe}, \mathrm{Cu}, \mathrm{Pb}$ and $\mathrm{Cd}$. These values were lower than unity as required which implies heavy metals in the powdered milk sample do not pose any significant threat and can therefore be normally consumed.

Regular monitoring of radionuclide and heavy metals in milk sample should be emphasized to prevent excessive build-up of the toxic metals in the food chain. Also movement of food stuff illegally into the country should be monitored. The data generated in this study will provide assistance in the development of future guidelines in Nigeria for radiological protection of the population.

\section{References}

1. Abollino O, Aceto M, Bruzzoniti MC, Mentasti E, Sarzanini C (1998) Speciation of copper and manganese in milk by solid - phase extraction/inductively coupled plasma-atomic emission spectrometry. Annals Chim Acta 375: 299306.

2. Buldini PL, Cavalli S, Sharma JL (2002) Matrix removal for the ion chromatographic determination of some trace elements in milk. Microchem Journal 72: 277-284.

3. Levy Y, Zeharoa A, Grunebaum M, Nitzan M, Steinherz R (1985) Copper deficiency in infants fed cow milk. J Pediatr 106: 786-788.

4. Melquiades FL, Appoloni CR (2001) Radiation of powdered milk produced at Londrina, PR, Brazil. Radiat Phys Chem 61: 691-692.

5. Melquiades FL, Appoloni CR $(2002){ }^{40} \mathrm{~K},{ }^{137} \mathrm{Cs}$ and ${ }^{232} \mathrm{Th}$ activities in Brazilian milk samples measured by gamma-ray spectrometry. India J Pure Appl Phys 40: 5-11.

6. Almasri MS, Mukallati $\mathrm{H}$, AlHamwi A, Khalili H, Hassan M, et al. (2004) Natura radionuclides in Syrian diet and their daily intake. J Radioanalyt and Nucl Chem 260: 405-412.

7. Navarrete JM, Martinez T, Cabrera L (2007) Comparative study between radioactive contamination in powder milk by Chernobly accident $(137 \mathrm{Cs})$ and natural radioactivity (40K). J Radioanalyt Nucl Chem 272: 277-279.
8. Desimoni J, Sives F, Errico L, Mustrantonio G, Taylor MA (2009) Activity levels of gamma emitters in Argentinean cow milk. J Food Compos and Analys 22 250-253.

9. Ababneh ZQ, Alyassin MA, Aljarrah KM, Ababneh AM (2010) Measurement of natural and artificial radioactivity in powdered milk consumed in Jordan and estimates of the corresponding annual effective dose. Radiation Protection Dosimetry 138: 278-283.

10. Strok M, Smodis B (2011) Natural radioactivity in milk from the vicinity of a former uranium mine. Nucl Eng Design 241: 1277-1281.

11. Emumejaye K (2012) Determination of Potassium - $40\left({ }^{40} \mathrm{k}\right)$ Concentration in Some Powdered Milk Samples Consumed In Delta State, Nigeria. IOSR J Appl Phys 2: 08-12.

12. Farai IP, Jibiri NN (2000) Terrestrial gamma radiation dose levels in Ibadan Nigeria. Nigeria Journal of Science 34: 195-199.

13. Olomo JB (1990) Natural radionuclide content of some Nigeria foodstuffs. Nucl Inst \& Meth Phys Res A299: 666-669.

14. Farai IP (1993) Measurement of 137 Cs in some post-Chernobyl milk products in Nigeria. Nigeria Journal of Science 27: 257-261.

15. Akinloye MK, Olomo JB (1999) Survey of Environmental Radiation Exposure around Obafemi Awolowo University Nuclear Research Facilities. Nigerian Journal of Physics 7:16-19

16. Steijns JM (2001) Milk ingredients as nutraceuticals. Int J Dairy Technol 54 81-88

17. Veiga R, Sanches N, Anjos RM, Macario K, Bastos J, et al. (2006) Measurement of natural radioactivity in Brazilian beach sands. Radiat Meas 41: 189-196.

18. Ademola AK, Bello AK, Adejumobi CA (2014) Determination of natural radioactivity and hazard in soil samples in and around gold mining area in Itagunmodi, southwestern, Nigeria. J Radiat Res \& Appl Sci 7: 249-255.

19. USEPA (2002) Preliminary Remediation Goals, Region 9.

20. USEPA (1997) US Environmental Protection Agency. Exposure Factors Handbook-General Factors. Office of Research and Development, National Center for Environmental Assessment, Washington DC.

21. FAO/WHO (1989) Evaluation of certain Food additives and contaminants. Technical Report series No. 505(1972), No. 555(1974c), No. 683(1982), No. 751(1987), No. 776 (1989), Geneva.

22. UNSCEAR (2000) Sources, Effects and Risks of lonizing Radiation. New York, United Nations.

23. Zain MA (2013) Assessment of Natural radionuclides in Powdered milk Consumed in Saudi Arabia and Estimates of the Corresponding annual Effective Dose. J American Sci 9: 267-273.

24. ICRP (1995) Age - dependent doses to members of the public from intake of radionuclides-Part5 Compilation of ingestion and inhalation coefficients. ICR Publication72, Oxford: Pergamon Press,UK.

25. Alzahrani JH (2012) Natural Radioactivity and Heavy Metals in Milk Consumed in Saudi Arabia and Population Dose Rate Estimates. Life Science Journal 9 : 651-656.

26. UNSCEAR (1993) Report to the General Assembly, United Nations, New York Ref $12-15$

27. Shanthi AG, ThampiThankaKumaran BG, AllanGnanaRaj G, Maniya C (2010) Natural radionuclides in the South Indian foods and their annual dose. Nucl Inst \& Meth Phys Res A 619: 436-440.

28. Ibrahim HS, Abdelfatah FH, Nadia HE, Hussen AM, Mohammed AN (2007) Radiolo-icalon Solids, Foodstuff and Fertilizers in the Alexandria region Egypt Turkish J Eng Env Sci 31: 9-17. 
Citation: Kolapo AA (2014) Assessments of Natural Radioactivity and Heavy Metals in Commonly Consumed Milk in Oke-Ogun Area, Nigeria and Estimation of Health Risk Hazard to the Population. J Environ Anal Toxicol 4: 253. doi: 10.4172/2161-0525.1000253

29. Hosseni T, Fathivand AA, Barati H, Karimi M (2006) Assessment of Radionuclides in Imported Foodstuffs in Iran. Int J Radiat 4: 149-153.

30. Yuzbasi N, Sezgin E, Yildirim M, Yildirim N (2003) Survey of lead, cadmium, iron, copper and zinc in Kasar cheese. Food Chemistry 20: 464-469.

31. Salah FA, Esmat IA, Mohamed AB (2013) Heavy metals residues and trace elements in milk powder marketed in Dakahlia Governorate. Int Food Res J 20: $1807-1812$
32. FAO/WHO Joint Expert Committee on Food Additives (1999) Summery and conclusions. 53 $3^{\text {rd }}$ Meeting, Rome.

33. Cui YL, Zhu YG, Zhai RH, Chen DY, Huan YZ, et al. (2004) Transfer of metals from soil to vegetables in an area near a smelter in Nanning, China. Environ Int 30: 785-791.

34. IAEA (1989) Measurement of Radiation in Food and the Environment. Technical Reports Series 295, Vienna. 